\title{
Op weg na 'n komprehensiewe geskiedenis van Ou-Israel
}

\author{
Eben Scheffler
}

\section{Abstract}

Towards a comprehensive history of ancient Israel

This paper reflects on the aim of ancient Israelite historiography and argues for a comprehensive approach to the history of Israel. In such an approach various aspects of that history (political, socio-cultural, religious and literary) and their dynamic mutual interrelation should be accounted for. The classification of the history in various historical periods should also integrate with this comprehensive approach.

\section{INLEIDING}

Hierdie artikel behels geen poging tot 'n omvattende konstruksie van die geskiedenis van Ou-Israel nie. Dit is eerder ' $n$ besinning van historiografie as sodanig, in soverre laasgenoemde op die geskiedenis van Ou-Israel, in al sy fasette, betrekking het. Dit besin oor riglyne wat by die beoefening van die Ou-Israelitiese historiografie aandag verdien.

Die tese van hierdie artikel is dat die geskiedenis van Israel in die verlede meesal slegs in beperkte mate bestudeer is deurdat slegs aan sekere aspekte van Ou-Israel se bestaan (gewoonlik die politiese en godsdienstige aspekte) aandag gegee is. Boonop het hierdie aspekte dan ook in isolasie van mekaar aandag geniet, met die gevolg dat verskeie belangrike insigte in die geskiedenis oor die hoof gesien is. Wat hier volg is ' $n$ betoog vir 'n komprehensiewe benadering tot die geskiedenis waarin alle aspekte van menslike bestaan, in hulle onderlinge wisselwerking met mekaar, onder die loep kom.

'n Komprehensiewe benadering tot die geskiedenis hang nou saam met die doel of beweegrede vir die bestudering van die geskiedenis van Ou-Israel.

Derhalwe word allereers verskeie beweegredes vir die bestudering van die geskiedenis van Israel kortliks bespreek. Daarna volg 'n 
bespreking van wat ons meen die omvattende objek van die geskiedenis van Ou-Israel behels. In die slotparagraaf word op die moontlike implikasies vir die beoefening van Ou-Testamentiese wetenskap gewys.

'n Komprehensiewe benadering tot die geskiedenis het ook implikasies vir die metodiek of werkswyse wat in so ' $n$ benadering gevolg word. Metodiese vrae regverdig egter 'n aparte besinning met die gevolg dat opmerkings wat in hierdie artikel daaroor gemaak sal word slegs kursories van aard sal wees.

\section{DIE DOEL VAN OU-ISRAELITIESE HISTORIOGRAFIE}

Afgesien van hoogs persoonlike redes waarom die geskiedenis van Ou-Israel bestudeer word, kan die volgende belangrikste beweegredes onderskei word:

Sommiges bestudeer die geskiedenis van Ou-Israel vanweë 'n mistiese belangstelling in die antieke. Vir baie navorsers (en belangstellende leke) hou nuwe kennis oor die antieke 'n bepaalde mistiese belewenis in. Argeoloë sal byvoorbeeld ure deurbring in die warm son van Palestina om maar net een potskerfie ongeskonde uit die grond te haal. ' $n$ Mistiese belangstelling in die verlede is uiteraard subjektief en kan as sodanig nie op wetenskaplikheid aanspraak maak nie. Erkenning moet egter verleen word aan die feit dat baie groteske wetenskaplike historiese ondersoeke in die verlede deur ' $n$ mistieke belangstelling in die geskiedenis gemotiveer is.

Tweedens bestudeer sommiges die geskiedenis van Ou-Israel vanweë religieuse redes. Hierdie groep mense (gewoonlik gelowige Christene en Jode) glo dat die volk Israel deur God uitverkies is en dat God dus in ' $n$ besondere sin in Ou-Israel se geskiedenis gewerk het en hom daarin geopenbaar het. Deur Ou-Israel se geskiedenis te bestudeer kom mens meer van God se openbaring te wete en dus meer van God self. Die gelowige wat uit religieuse oorwegings die geskiedenis van $\mathrm{Ou}$ Israel bestudeer, moet egter waak om nie al te gou die geskiedenis in terme van sy geloofsveronderstellinge te interpreteer nie. Die hermeneutiese konklusies wat die gelowige met die oog op sy eie lewe maak moet sover moontlik losgemaak word van die poging tot 'objektiewe' bestudering van die geskiedenis opsigself waarin geloof as sodanig geen rol speel nie.

Derdens word geskiedenis bestudeer met die oog op die lesse wat 
daaruit te leer is. As sodanig kan, maar hoef 'n religieuse interpretasie nie by sodanige relevantmaking van die geskiedenis betrokke te wees nie. Die doel hier is om te leer en wys te word uit ander se ervaringe en foute. Indien die koning van Juda voor die ballingskap byvoorbeeld na die profeet Jeremia geluister het en ongeregtigheid uit die land uitgeroei het, kon die katastrofe van die ballingskap moontlik vermy gewees het. ' $n$ Hedendaagse politieke leier kan moontlik besluit om wyser as die koning van Juda destyds op te tree en hom te laat adviseer in sake ongeregtigheid in sy eie land. Mense wat ter wille van die lesse wat uit die geskiedenis te leer is die geskiedenis bestudeer met die oog op groter wysheid, glo gewoonlik aan die spreekwoord wat sê: 'Die geskiedenis herhaal homself'. Soos wat die geval is met die 'religieuse' motivering, moet die bestudeerder van die geskiedenis ter wille van groter wysheid egter ook waak om nie al te gou die geskiedenis te interpreteer in terme van die 'lesse' wat hy wil leer nie. Alhoewel absolute objektiwiteit nooit haalbaar is in die geskiedskrywing nie, moet die geskiedskrywer altyd poog om van sy voorveronderstellings bewus te wees en onbevangenheid sover moontlik nastreef.

Vierdens word die verlede bestudeer as gevolg van eksistensiële redes. Volgens hierdie opvatting is die geskiedenis vir elke mens belangrik of hy dit nou self wil erken of nie. Die eenvoudige rede hiervoor is dat elke mens deel van die geskiedenis en as 't ware self geskiedenis is (vgl Bultmann 1983: 7-15). Die Ou-Israeliete was ook mense en was deel van dieselfde omvattende wêreldgeskiedenis waarvan die hedendaagse mens ook deel is. Om die waarheid te sê, dit is per slot van sake die geskiedenis wat die moderne mens aan die antieke mens bind. Die moderne mens word ook bepaal deur die geskiedenis en misken dus sy eie bestaan indien hy die geskiedenis misken. Die moderne mens en die antieke mens is broers en susters van mekaar (des te meer as die religieuse interpretasie van die geskiedenis ook hier in berekening gebring word). Dit gaan dus om die nagaan van die eie oorspronge en om solidariteit met die mens wat eeue voor ons geleef het.

Vyfdens word die geskiedenis van Ou-Israel bestudeer om die Bybel beter te verstaan. Vir die beoefening van die Ou-Testamentiese wetenskap as sodanig is laasgenoemde in 'n besondere sin relevant. Vir die Ou Testamentikus is dit reeds ou nuus dat elke Bybelboek binne sy eie historiese konteks en teen sy eie agtergrond verstaan moet word. In hierdie verband is die ontstaanstyd, die outeur en die destydse gehoor of eerste lesers van elke Bybelboek belangrik. Dit is egter nie al nie. Die 
gebeure waaroor daar in spesifieke Bybelboeke berig word, moet ook gekorreleer word met die geskiedenis wat hom destyds afgespeel het. So nie is die Bybel vatbaar vir allerlei onkontroleerbare allegoriese interpretasies wat bo die werklikheid sweef en met die geskiedenis en die werklike lewe niks te make het nie. Vir die Ou Testamentikus is dit ook reeds ou nuus dat ons in die Bybel met allerlei historiese probleme te make het (vgl Deist et al 1981). Wat is byvoorbeeld die historiese verband tussen die aartsvaders en die latere Israel? Wat was die verhouding tussen die mense van die uittog en die aartsvadergroepe? Wanneer en waar het die struktuur van die twaalf stamme ontstaan (vgl Deist \& Du Plessis 1982: 4)? Die geskiedskrywing probeer nie slegs om hierdie en soortgelyke probleme op te los met die oog daarop dat ons kan weet wat werklik gebeur het nie. Die geskiedskrywing bestudeer hierdie aangeleenthede aangesien die probeleme deur die teks van die Bybel opgewerp word en die teks van die Bybel sonder ' $n$ moontlike poging om hierdie vrae te beantwoord in baie opsigte 'n geslote boek sal bly. Kortom: Wetenskaplike integriteit eis van die eksegeet om te poog om die Bybel histories te verstaan. Ten spyte van die feit dat ons die geskiedenis nooit volledig kan ken nie, behels 'histories verstaan' dat die bestudering van die geskiedenis vir die Ou Testamentikus onontbeerlik is.

Die geskiedenis kan ook ter wille van die geskiedenis self bestudeer word. Daar hoef nie telkens aangetoon te word hoe die geskiedenis die eksegeet help om die teks van die Bybel beter te verstaan nie. Daar hoef ook nie voortdurend gefilosofeer te word oor die verbondenheid van die moderne mens met mense van weleer nie. Die oplettende leser sal wel in staat wees om hierdie afleidings self te maak. Alhoewel die bestudering van die geskiedenis ter wille van die verstaan van die Bybelse teks vir die Ou-Testamentikus belangrik is, beteken dit ook glad nie dat die geskiedsnavorser ook doelbewus van al hierdie 'motiverings' ontslae moet raak nie. Dit is goedskiks moontlik dat 'n persoon die sin van meer as een (of selfs almal) van bogenoemde motiverings sal insien. Dit kan ook wees dat mens die motiverings (tesame met aspekte wat nie hierbo genoem is nie) kan integreer in 'n eie unieke motivering oor waarom mens nou eintlik geskiedenis bestudeer. Wat egter ook al die motivering vir die bestudering van die geskiedenis van Ou-Israel is, is dit ons betoog dat slegs ' $n$ omvattende benadering tot die bestudering van die geskiedenis, van die grootste verskeidenheid oogmerke en motiewe rekenskap kan gee. Die mens van vandag leef in 'n totale konteks (polities, sosio-kultureel en gods- 
dienstig) en slegs die bestudering van die verlede in laasgenoemde se totale konteks bied die wyds moontlike ervaringsveld om vir die moderne mens enigsins van betekenis te wees.

\section{DIE OMVATTENDE OBJEK VAN DIE GESKIEDENIS VAN OU-ISRAEL}

Ten einde die objek van die geskiedenis van Ou-Israel te bepaal moet die verskillende aspekte van die lewe van Ou-Israel, sowel as die periode en subperiodes van die geskiedenis wat bestudeer of beskryf wil word, onder die loep kom.

\subsection{Meerdimensionele Ou-Israelitiese historiografie}

Indien die geskiedenis van 'n bepaalde volk of land geskryf word, is die neiging dikwels om die betrokke geskiedenis te laat sentreer rondom wat beskou word as die belangrikste persone binne die samelewing, naamlik die politici. Geskiedenis is dus vir baie per definisie politieke geskiedenis. Die lewe van Jan Alleman sou slegs dan ter sprake kom indien dit van direkte belang is vir dit wat sigself op politieke gebied afspeel. Dieselfde geld vir godsdienstige instellings: Laasgenoemde word slegs betrek in soverre dit in verhouding met die staat staan.

Hierdie wyse van geskiedskrywing word vandag toenemend bevraagteken. Dat geskiedenis per definisie politieke geskiedenis sou wees, word geag 'n oorblyfsel te wees van die fase van analistiese geskiedskrywing toe die geskiedenis hom as 't ware aan die hof van die konings en die vorste afgespeel het (vgl Deist 1987). Alhoewel geskiedskrywing later nie noodwendig vanuit die perspektief van die konings of politici bedryf is nie, is dit nog steeds merendeels óor hulle gedoen.

Sonder om die belangrike (en in baie opsigte selfs bepalende) invloed van die politieke aspek te ontken, is geskiedskrywing vandag veral geïnteresseerd in die mense wat in 'n bepaalde tydvak geleef het en dan veral die mens binne die konteks van die samelewing waarin hulle geleef het. Alle aspekte van menslike lewe (ook die politiek) is dan belangrik en staan in dinamiese wisselwerking tot mekaar. Wanneer ons meer van die mens van 'n bepaalde tydvak wil weet, moet aan alle aspekte van sy lewe aandag gegee word, insluitende dit wat vir homself belangrik was. Ons sou derhalwe kon sê dat daar 'n ontwikkeling gekom het van politieke geskiedenis na samelewingsgeskiedenis (vgl 
Heyns 1986). Nie slegs die politiek nie, maar die samelewing in sy geheel is nou die objek van die geskiedenis.

Die keuse vir 'n komprehensiewe geskiedskrywing word dus veral gemotiveer deur die insig dat dit die kompleksiteit van die totale lewe is wat gebeure op 'n bepaalde gebied beïnvloed en bepaal. Politiek, godsdiens, kultuur en letterkunde werk onderling op mekaar in. Om dus slegs op deelaspekte in isolasie te konsentreer sou dus ' $n$ skewe beeld van die geskiedenis in die hand kon werk.

Verder impliseer 'n komprehensiewe benadering tot die geskiedenis van Ou-Israel ook 'n meer demokratiese visie op die werklikheid wat die uitgangspunt bevraagteken dat slegs konings en aristokrate 'geskiedenis kan maak'. Die lewe van die gewone man (sy doen en late, belewenisse en beskouings) word as minstens netso belangrik as die van die hoër lui geag.

Ten einde aan alle aspekte van die menslike lewe reg te laat geskied in die skryf van geskiedenis, sou dit loon om vooraf kategorieë te onderskei en te selekteer wat na ons mening die verskillende uiteenlopende aspekte van menslike lewe genoegsaam dek. Vervolgens word dus kortliks aandag geskenk aan die politieke, kulturele, godsdienstige en literatuurhistoriese aspekte in die bestudering van die geskiedenis van Ou-Israel.

\subsubsection{Die politieke aspek van Israel se geskiedenis}

Die bestudering van Israel se geskiedenis as samelewingsgeskiedenis in plaas van eksklusiewe politieke geskiedenis mag geensins daartoe aanleiding gee dat die politieke komponent van die geskiedenis verwaarloos word nie. Binne die samelewing is politici in 'n groot mate 'n bepaler van die historiese verloop van sake, veral as gevolg van die mag wat politici gewoonlik het. As verklaarders van oorlog byvoorbeeld, word die lot van die gewone man wat in die oorlog veg in 'n baie groot mate deur politici bepaal (vgl bv die lot van Urija aan die hand van koning Dawid, 2 Sam 11).

Binne die politieke aspek van die samelewing kan verder onderskei word tussen internasionale en binnelandse politiek. Hierdie onderskeid is belangrik aangesien politici se besluite nie slegs vanuit binnelandse oorwegings (bv behoeftes van die volk) gemotiveer word nie maar ook vanuit die buitelandse verhoudinge waarin hulle staan.

Wat die internasionaal-politiese aspek van Israel se geskiedenis betref kom die breë Oud-Oosterse geskiedenis, waarvan Israel deel uitgemaak het, ter sprake. Ou-Israel se kontak met en ook konflikte en 
oorloë met sy bure word telkens in die Bybel aangeroer. Vir die verstaan van Israel se eie geskiedenis is ' $n$ bepaalde kennis van die volke wat hom omring het dus onontbeerlik. Vir elke tydvak afsonderlik sal afgevra moet word in watter mate hierdie volke die geskiedenis van Israel beïnvloed het.

Die buurvolke wat 'n groot invloed op die verloop van Israel se geskiedenis uitgeoefen het en dus aandag verdien is veral die Kanaäniete, die Filistyne, die Egiptenare, die Amoriete, die Arameërs, die Assiriërs, die Babiloniërs, die Hetiete, die Moabiete, die Feniciërs en die Persiërs. Van hierdie volke was gedurende hulle bloeityd wêreldmagte wat die politieke toneel in die Ou Nabye Ooste (en dus ook Israel) oorheers het. Dit is egter nie die taak van die historiograaf van Ou-Israel om die geskiedenisse van hierdie volke ook in detail na te vors nie. Veel eerder kan gesteun word op die resultate van navorsers in hierdie veld (vgl Wiseman 1973; Noth 1977; Schwantes 1969; Hallo \& Simpson 1971; Van Zyl et al 1979; Reicke 1970). Op aspekte van hierdie volke se geskiedenis wat raakpunte met die van Ou-Israel vertoon, sal die geskiedskrywer van Ou-Israel egter wel dieper ingaan as selfs sy Ou-Oosterse eweknie.

Wat die binnelandse politieke aspek van die geskiedenis betref word daar allereers aandag gegee aan die politieke instellings self. Dit is bekend dat Israel kort na sy vestiging as volk in Palestina aanvanklik deur rigters geregeer is en dat die oorgang na 'n koninkryk geensins vanselfsprekend was nie. Dit is ook bekend dat terwyl daar verskillende koninkryke was (Noord en Suid) die beskouings oor die posisie van die koning ook verskil het. Die historikus sal derhalwe moet aandag gee aan die ontwikkeling van die staatskonsep in Ou-Israel - dit sluit die na-ballingskapse tyd in toe Israel (Juda) nie meer onafhanklik was nie. Die vorste wat toe relatiewe politieke mag binne Israel gehad het, was hoegenaamd nie meer konings in die sin van koning Dawid nie. Aan die politieke verlangens binne Israel, (die Dawidiese restourasiehoop of die verlange na die herstel van die Dawidsryk) moet dan ook in hierdie verband aandag gegee word.

Aandag sal ook geskenk moet word aan die persoon van die koning (hoe is hy gesalf, gekroon, wat was sy status), die koningshuishouding (die posisie van sy harem, sy koningin, sy bediendes, lyfwag ens) en die regering van die koning (sy ministers, sekretarisse, bodes ens).

Vervolgens sal die historikus dan ondersoek hoe die koning die land geregeer of geadministreer het. Met ander woorde, wat was sy binnelandse beleid? Hoe het hy sy invloed laat geld op die ander terreine in 
die samelewing wat saam die geskiedenis uitmaak? Hoe het sy regering en administrasie die lewe van die gewone man beïvloed? Hier word veral aandag gegee aan ekonomiese aspekte (soos belastings, publieke werke, landbou) en byvoorbeeld die regspraak en weermag, asook sy verhouding met die religieuse instellings (vgl De Vaux 1968: $91 \mathrm{vv}$ ).

Wat die koning se verhouding tot die maatskappy waarvan hy koning was betref, moet in gedagte gehou word dat daar noue oorvleueling bestaan tussen die politieke en sosio-kulturele aspekte van die geskiedenis. Laasgenoemde moet weer afsonderlik aan die orde kom aangesien die koning of politici se invloed op die sosio-kulturele lewe (alhoewel belangrik), volgens 'n komprehensiewe opvatting van die geskiedenis, beslis nie die somtotaal van die sosio-kulturele lewe uitgemaak het nie. Dit hoort tot die kuns van die geskiedskrywer om sy geskiedenis op so 'n wyse aan te bied dat hy onderskei tussen stof wat hy onder die politieke aspek noem en dit wat hy met die minimum herhaling weer onder die ander aspekte opneem tesame met inligting wat hy slegs onder die sosio-kulturele aspekte te berde sal laat kom.

In sy poging om die politieke geskiedenis te konstrueer sal die historikus aansluit by die weergawe van die Bybelse geskrifte wat oor die breë politieke sake handel. Hy sal ook probeer om gegewens wat hy versamel te korreleer met buite-Bybelse literatuur (bv die Assiriese koninklike inskripsies). Vir hierdie aspek van die geskiedenis sal die bestudering van argeologiese gegewens slegs van beperkte belang wees aangesien argeologiese artefakte nie artefakte van eenmalige gebeurtenisse is nie.

\subsubsection{Die sosio-kulturele aspek van IsraeI se geskiedenis}

Onder hierdie kategorie hoort eintlik alle aspekte tuis wat nie in die vorige punt genoem is nie. Twee aspekte (die godsdienstige en literatuur-historiese) wat ook streng gesproke hier kan ressorteer, word egter (om redes wat aanstons genoem sal word) nie hier onder die loep geneem nie. Met die sosio-kulturele aspek van die geskiedenis word enige moontlike aspek van die burgerlike lewe bedoel. Ons noem slegs die volgende:

\subsubsection{Die ekonomiese lewe}

Hoe het die Ou-Israeliet sy bestaan gemaak? Het hulle slegs geboer of was daar ook vorme van industrieë en handel? Wat van beroepe soos pottebakker, skrynwerkers, vissermanne, tentmakers, skrywers en belastinggaarders (vgl Gilbertson 1959: 93 vv)? Watter ekonomiese sis- 
teem was daar? Was daar so iets soos private besitreg of was daar 'n unieke vorm van sosialisme? Wat was die verhouding tussen ryk en arm in die land binne 'n bepaalde tydvak en hoe het dit die politieke en godsdienstige lewe beïnvloed (vgl bv Miga en Amos)? In watter tipe huise het die mense gebly (vgl Gilbertson 1959: $7 \mathrm{vv}$ )? Watter regsmaatreëls was daar wat 'n invloed uitgeoefen het op die ekonomiese lewe (bv die sabbatsjaar en jubeljaar)? Hoe het die koning se binnelandse beleid die ekonomiese lewe van die gewone man beïnvloed (vgl bv die uitgebreide ekonomiese aktiwiteite van Salomo met sy groot ekonomiese projekte en dwangarbeid). Hoe het die boere geboer (vgl bv die inligting wat die moderne streeksargeologie vandag beskikbaar maak, vgl Dever 1982 en Deist 1987: 79)? Watter mates, gewigte en geldeenheid het die Israeliete gebruik (De Vaux 1968: $195 \mathrm{vv}$ )? Hoe het die religieuse feeste (veral oesfeeste) met die ekonomiese lewe in verband gestaan (De Vaux 1986: 484)?

\subsubsection{Die familielewe}

Hoe het die uitgebreide patriargale familie (sg 'extended family') daaruitgesien, veral as mens dit vergelyk met die Westerse nuklieêre familie? Hoe het die huwelik gelyk (bv poligamie teenoor monogamie)? Was die huwelik 'n staatsinstelling met regsimplikasies soos ons dit vandag het of was dit bloot 'n familieinstelling? Wat was die leviraatshuwelik? Wat was die posisie van vrouens, weduwees en kinders binne die familie en die samelewing? Hoe kon familielede erf en hoe het familielede hulle geliefdes begrawe? Welke verandering was daar in die algemene beskouings ten opsigte van hierdie sake met verloop van tyd? Die historikus moet daarteen waak om nie gebruike en beskouings wat vir'n spesifieke tyd gegeld het te veralgemeen asof dit vir alle tye net so gegeld het nie (vgl De Vaux 1968: 19 vv; Gilbertson 1959: 41-51).

\subsubsection{Kuns en wetenskap}

Fasette van Ou-Israelitiese kuns kan bestudeer word in reste van hulle pottebakkerswerk wat deur argeologiese opgrawings beskikbaar gemaak word. Op die potte is meermale tekeninge aangebring wat ook mettertyd ontwikkel het. Om uit die ontwikkeling van kunsvorme afleidings te maak oor ' $n$ moontlike ontwikkeling in tydsgees is uit die aard van die saak geen geringe taak nie, maar dit lê nie buite die sfeer van historiese ondersoek nie. Naas die skilderkuns is musiek ook as kunsvorm beoefen soos ons vroeg in die Bybel reeds kan aflei uit Genesis 4: 21: 'Die naam van sy broer was Jubal en hy was die 
stamvader van dié wat op die lier en die fluit speel'. In die volgende vers lees ons weer van Tubal-Kain "'n smid, 'n vakman in koper en yster'. Daar was dus in die loop van Israel se geskiedenis 'n ontwikkeling op die gebied van kuns en wetenskap en dit is die historikus se taak om nie slegs hierdie ontwikkeling binne Israel na te speur nie maar om dit te vergelyk met die algemene ontwikkeling in die Ou Nabye Ooste. Was Israel voor of agter sy omliggende bure wat sodanige ontwikkeling betref? In watter mate het agterstand op sodanige gebied die verloop van politieke sake beïnvloed (vgl bv die intog en besetting van die land)?

\subsubsection{Die regspraak}

In die Pentateug word die neerslag van uitgebreide wetgewing wat in Ou-Israel geheers het gevind. Weer eens is dit die historikus se taak om die reg nie alleen te beskryf nie, maar ook om bepaalde ontwikkelinge aan te toon (vgl bv die weergawe van die dekaloog in die boek Eksodus teenoor Deuteronomium). Die verband tussen Israelitiese wetgewing en die van die Ou Nabye Ooste (vgl bv die Kodeks van koning Hammurabi) moet ondersoek word en die unieke van Israel (indien enige) moet aangetoon word. Wat was die koning se wetlike en uitvoerende bevoegdhede? Hoe het die regters en geregshowe gefunksioneer (in die rigtertyd was die amp van regter en vors skynbaar dieselfde) in die verskillende tydvakke? Watter strawwe is opgelê? Was daar byvoorbeeld ' $n$ ontwikkeling ten opsigte van die beskouing ten opsigte van doodstraf? Watter plek is aan godsdiens in die regspraak gegee (vgl die siening van God as die finale regter en handhawer van geregtigheid)? Watter vorme van begenadiging (vgl bv die sogenaamde vrystede) was moontlik binne die regspraak van Ou-Israel (vgl De Vaux 1968: 143 vv en Deist 1986: 103 vv)?

\subsubsection{Sosiale status}

Die sosiale stratifikasie van Ou-Israel het gevarieer vanaf vrymense met hoë invloed in die samelewing tot lewenslange slawe. Watter mense het ' $n$ hoë posisie in die samelewing beklee? Het sodanige posisie saamgehang met finansiële rykdom of dalk (ook?) met die beoefening van 'n bepaalde beroep? Wie en wat was die sogenaamde 'volk van die land' (am hares)? Was daar 'n verskil in sosiale posisie tussen die sogenaamde 'vreemdelinge' of uitlanders wat in Israel se midde gewoon het en die Israeliete self? Indien daar 'n verskil was, wat was dit en hoedanig het die posisie van die vreemdelinge verander? Wat was die kritiek van die 
profete ten opsigte van die behandeling van vreemdelinge (vgl bv Jer 7: 5)? Wat was die posisie ten opsigte van slawe? Wat was die verskil tussen buitelandse slawe en Israelitiese slawe? Watter regte het slawe gehad? Wat van slavinne? Hoe kon slawe vry word of kon hulle nooit? (vgl De Vaux 1968: 65 vv).

\subsubsection{Opvoeding}

Hoe het die Ou-Israeliet sy kind geleer? Was dit by wyse van informele of formele onderrig? Dit wil voorkom asof kennis in die vroeër tye mondeling oorgelewer is van ouers tot kinders. Die inhoud van die onderrig was hoofsaaklik die wet van Moses, maar vaardighede in allerlei ambagte wat vir spesifieke beroepe nodig was sou noodwendig ook aandag moes geniet. Watter invloed het die opbloei van die skryfkuns (ongeveer 1200-1000 vC) op die opvoeding in Ou-Israel uitgeoefen? Klaarblyklik het daar ook in later tye rondom die sinagoge 'n skool ontstaan waar meer formeel onderrig gegee is. Wysheidskole het ook ontstaan waarin selfs volwassenes onderrig ontvang het in die 'kuns om te lewe' (vgl Pred 12: 9). Met die optekening van die wet en die eerste terboekstawing van die geskiedenis van Ou-Israel (die Jahwis, ongeveer $1000 \mathrm{vC}$ ) was opvoeding ook nie meer beperk tot mondelinge oordrag nie. Die vraag moet ook gevra word in watter mate daar in Ou-Israel 'n verskil was tussen sekulêre en religieuse opvoeding. Dit wil voorkom of die opvoeding primêr religieus van aard was (vgl Gilbertson 1959: 124 vv).

\subsubsection{Die militêre lewe}

Alhoewel die militêre aspek van Ou-Israel se lewe noodwendig ten nouste gebonde is aan die politieke aspek (dit was immers die politici wat besluit het om oorlog te maak), was daar tog aspekte wat konstant gebly het al het die politici gekom en gegaan. Hoe is daar byvoorbeeld oorlog gevoer? Was daar 'n professionele weermag of was militêre diens verplig, of het dit gewissel van tyd tot tyd? Hoe is stede en dorpe gefortifiseer met die oog op oorlog? Watter tipe wapentuig is gebruik? In watter oorloë was Israel betrokke? Wat was die verhouding tussen oorlog en godsdiens (vgl die sogenaamde heilige oorlog)? (De Vaux 1968: $213 \mathrm{vv}$ ).

Bogenoemde aspekte (wat ons as die vernaamste beskou) dek nie noodwendig die sosio-kulturele lewe van Ou-Israel nie. Dit kan gebeur dat in sekere fases van die geskiedenis sommige aspekte sal opdoem wat as ' $t$ ware die aandag sal beheers. In beginsel is geen aspek van 
menslike lewe egter onbelangrik nie en die beklemtoning van sommige aspekte as belangriker as die ander is slegs 'n relatiewe beklemtoning. Geen antieke Israeliet leef ongelukkig vandag om vir die moderne mens mee te deel wat vir hom in die lewe belangrik was nie. Alhoewel ons dus nooit sal kan aanspraak maak op 'n volledige of totaal omvattende weergawe van die geskiedenis van die mense van Ou-Israel nie, moet die individuele antieke Israeliet asook die volk as geheel egter voortdurend voor die geestesoog gehou word en moet die historikus poog om hom in te dink hoe die lewe vir hulle sou gewees het. Deur eksplisiet seker te maak dat in die bestudering van elke tydvak van Ou-Israel se geskiedenis aan bogenoemde aspekte aandag gegee word, kan die moontlikheid verklein word dat sake verwaarloos sal word wat wel histories belangwekkend is.

Tesame met ' $n$ kritiese gebruik van die bybelse literatuur (in soverre as wat laasgenoemde sosio-kulturele sake reflekteer), sal die historikus hom wat die kulturele aspek van die geskiedenis betref veral op argeologiese gegewens verlaat. Argeologiese artefakte is in baie opsigte veel meer 'n getuienis van die alledaagse lewe as van groot politieke gebeurtenisse.

\subsubsection{Die ideologies-godsdienstige aspek van Israel se geskiedenis}

Die godsdiens van ' $n$ bepaalde volk kan goedskiks beskou word as deel van sy kultuur. Aangesien godsdiens by uitnemendheid so ' $n$ belangrike plek in Ou-Israel se lewe ingeneem het, verg dit egter 'n aparte bespreking. Soos reeds geblyk het, staan haas elke ander aspek van die lewe van Ou-Israel in verband met sy godsdienstige lewe, wat weer net die belangrikheid van laasgenoemde beklemtoon. Die godsdienstige beskouings en die ontwikkeling daarvan in die geskiedenis sal derhalwe so weergegee moet word dat die relasie tussen godsdiens en politiek, ekonomie, regspraak ensovoorts telkens sal blyk. In baie gevalle is godsdienstige en polities-ideologiese beskouings so met mekaar verweef dat dit beter is om (soos in die opskrif van hierdie paragraaf) eerder te praat van die ideologies-godsdienstige aspek van Ou-Israel se geskiedenis as bloot net die 'suiwere' godsdienstige aspek daarvan.

Om die godsdiens van Ou-Israel in al sy fases te verstaan is dit egter raadsaam om ' $n$ onderskeid te tref tussen Israel se godsdienstige instellings en sy godsdienstige beskouings. Terwyl dit gedoen word, moet egter telkens weer gevra word na die verband tussen beide.

Wat die godsdienstige instellings betref kom die aanbiddingsplek 
van die Ou-Israeliet eerstens ter sprake. Dit is bekend dat die tempel sedert Salomo se tyd die sentrale aanbiddingsplek geword het. Voor dit het verskeie heiligdomme 'n rol gespeel (vgl die heiligdomme te Sigem, Bethel, Mammre, Gilgal, Silo ens). Die Kanaäniete het op verskeie 'hoogtes' aanbid en hulle gewoontes was nie sonder invloed in OuIsrael nie (vgl bv Agab). Wat die tempel betref is laasgenoemde se geskiedenis (oa die verwoesting daarvan en heropbou na die ballingskap) opsigself belangrik. Nie alleen het dit gegeld as aanbiddingsplek nie maar die sentralisasie van die kultus rondom die tempel het ook 'n saambindende krag uitgeoefen wat nie sonder ideologies-politieke konnotasies was nie.

Wie het die Israeliete in hulle aanbidding voorgegaan? Die historikus sal die funksies van die priesters (lering, offer, middelaar, voorleser uit die wet, optekenaar van die wet, vgl die P-bron) in die onderskeie fases van die geskiedenis moet ondersoek. Ook die veranderde rol van die priester tydens die ballingskap (vgl bv Esegiël). Daar sal ook aandag gegee moet word aan die innerlike konflikte binne die priesterdom (Sadokiete, Leviete, vgl Hanson 1979).

Hoe het die Ou-Israeliete aanbid? Hier moet veral aandag gegee word aan die funksie van die altaar en die verskeie soorte offers (bv sondoffers, brandoffers, versoeningsoffers ens). Hoe het die Israelitiese offer ontstaan (vgl die moontlike ontwikkeling uit die Kanaänitiese offer) en wat was die religieuse betekenis daarvan (versoening, gemeenskap met God)? Was die offer die enigste belangrike kultiese handeling? Wat van liturgiese gebede, reinigingsrites en toewydingsrites?

Wanneer het die Ou-Israeliete aanbid? Hoe het hulle liturgiese kalender daaruit gesien? As die belangrikste heilige dag is die geskiedenis van die sabbat uiteraard belangrik (vgl die moontlike Babiloniese, Kanaänitiese of Kenitiese oorsprong). Daar was egter ook ander besondere religieuse feesdae wat in die verloop van die geskiedenis ontstaan het (vgl die Paasfees, die fees van die weke of Pinksterfees, die loofhuttefees, die nuwejaarsfees, die groot versoendag, die tempelwydingsfees en die purimfees). Die oorsprong van hierdie feeste, sowel as hulle sosiale funksie is vir die historikus van belang. Wat het hulle gedenk of wat het hulle gevier (bv die oes)? Aan watter historiese gebeurtenisse was sommiges van hulle gekoppel en watter ideologiespolitiese betekenis het hulle koppeling aan sodanige gebeurtenisse geïmpliseer (vgl De Vaux 1968: 271 vv; Gilbertson 1959: 52 vv)?

Die bestudering van die religieus-ideologiese beskouings binne 
Ou-Israel is nie slegs die belangrikste aspek van sy godsdiensgeskiedenis nie maar ook moontlik die belangrikste aspek van sy geskiedenis self. Die geloof was sterk in Israel dat sy geskiedenis nou verbonde met God was deurdat God by uitnemendheid in hulle geskiedenis ingegryp het. Inderdaad is alles wat met hulle gebeur het binne ' $n$ religeuse raamwerk geïnterpreteer. Politieke gebeurtenisse soos byvoorbeeld die ballingskap was nie vir hulle suiwere politieke gebeurtenisse nie. Die grense tussen Israel se politieke en godsdienstige beskouings was dus deur die verloop van sy geskiedenis hoogs vloeibaar.

Aan Ou-Israel se religieuse beskouings sal aandag gegee moet word binne die konteks van die ontwikkeling van die beskouings binne die geskiedenis van Israel (vgl Schmidt 1982a). Die volgende sake is van belang:

- Die godsdiens van die patriarge

- Die godsbeskouing soos weerspieël in die Eksodustradisie

- Moses en die Jahwisme

- Die Kanaänitiese godsdiens en sy invloed op die Jahwisme

- Die godsdiens van twaalfstammefederasie

- Die Jahwisme van die verenigde koninkryk onder Dawid en Salomo

- Die deuteronomistiese teologie van die noordryk

- Die Sionsteologie van die suidryk

- Die godsdienstige kritiek van die profete

- Die invloed van die ballingskap op die godsdiens van Israel (deuteronomistiese teologie, Deutero-Jesajaanse universalisme, priesterlike en kronistiese teologie)

- Die apokaliptiese strominge in die na-eksiliese tyd (vgl Hanson 1979)

- Die wysheidstrominge

In die bespreking van die godsdienstige beskouings soos wat hulle hul neerslag in bogenoemde tydvakke gevind het sal godsdienstige opvattinge oor sake soos God, die skepping, verlossing, die mens, Satan engele en demone, die dood, die toekomsverwagting (eskatologie) ensovoorts, telkens onder die loep kom.

Verskeie godsdiensgeskiedenisse is al geskryf oor die godsdiens van Ou-Israel (vgl Ringgren 1963; Fohrer 1969; Schmidt 1982a; Deist \& Du Plessis 1982). Binne die raamwerk van 'n komprehensiewe benadering tot die geskiedenis van Ou-Israel word die godsdiens van Israel egter nie in isolasie met die ander aspekte van sy geskiedenis bestudeer nie, maar juis in wisselwerking daarmee.

Die belangrikste bron van inligting vir hierdie aspek van die geskie- 
denis is weer eens die geskrifte van die Bybel en dan veral die gesigspunte (points of view) van die outeurs van die geskrifte asook van diegene oor wie hulle berig. Vergelyking met buite-Bybelse literatuur is ook noodsaaklik aangesien sodanige vergelyking meermale die besondere (aldan nie) van die beskouings wat in Israel geheers het in reliëf plaas.

\subsubsection{Die literêre aspek van Israel se geskiedenis}

Die literêre werke wat in Ou-Israel geproduseer is, het vir 'n groot deel daarvan sy neerslag in die Ou Testament (Hebreeuse Bybel en Septuaginta) gevind. Soos wat dit met die godsdienstige aspek van sy geskiedenis die geval is, hoort die produsering van literêre werke eintlik tuis onder die kulturele aspek van Israel se geskiedenis. Weer eens regverdig die ontstaansgeskiedenis van die Ou Testament egter'n aparte bespreking vanweë die sentrale posisie wat dit in die geskiedenis van Ou-Israel beklee. Die geskiedenis van Ou-Israel het nie alleen die $\mathrm{Ou}$ Testament voortgebring nie, maar die tradisies wat in die $\mathrm{Ou}$ Testament sy neerslag gevind het, het ook 'n groot invloed op die geskiedenis van Ou-Israel uitgeoefen. Verder is die Ou Testament ook een van die belangrikste bronne by die bestudering van die geskiedenis van Ou-Israel. Om dit as bron verantwoordelik te kan gebruik, moet die historikus derhalwe ook op hoogte wees van die verskillende dele van die Ou Testament se eie plek in die geskiedenis van Ou-Israel. Verskeie sake moet verder in gedagte gehou word.

Eerstens gaan dit nie slegs om die kanonieke geskrifte van Ou-Israel nie. Voor die afsluiting van die Hebreeuse kanon (ongeveer 100 n.C.) het nie-kanonieke geskrifte ook ' $n$ rol in Israel se geskiedenis gespeel. Ook al was hulle nie noodwendig met dieselfde gesag bejeën as die kanonieke geskrifte nie, is hulle daarom beslis nie histories onbelangrik nie. Buitebybelse geskrifte (Babilonies, Assiries ens) verg ook die aandag in soverre as wat tradisies wat in die Israelitiese literatuur sy neerslag gevind het, hul vroegste oorspronge reeds daar het.

Tweedens is dit nie die taak van die historikus (wat besig is met die skryf van 'n komprehensiewe geskiedenis van Israel) om die literatuur wat hy aan die orde stel in besonderhede te ontleed nie. Dit is eerder sy taak om die verskillende geskrifte wat betref hulle ontstaantyd, outeurs, adres en ideologiese intensie binne die raamwerk van 'n spesifieke historiese tydvak in te pas.

Wat laasgenoemde betref, moet derdens in gedagte gehou word dat daar skerp onderskei moet word tussen die ontstaantyd van 'n geskrif 
en die tyd waaroor die geskrif berig. Ons weet byvoorbeeld dat Genesis 1 oor die skepping berig, maar beslis nie reeds by die skepping ontstaan het nie. Dieselfde geld vir groot dele van die Bybel. Dit kan dus gebeur dat' $n$ spesifieke geskrif twee keer in die aanbieding van die geskiedenis genoem sal word, in die tyd waaroor dit berig, sowel as die tyd waarin dit ontstaan het. So sal die Deuteronomistiese geskiedwerk as bron gebruik word indien die geskiedenis van die konings beskryf word, maar daar sal veral ook gevra word na die tyd wanneer die geskrif geskryf is (ballingskap) en wat die geskrif in dáárdie tyd wou kommunikeer. Sodoende word daar dan ook vanuit die bespreking van die geskrifte 'n brug geslaan na die ander aspekte van die geskiedenis van Ou-Israel.

Vierdens moet ook in gedagte gehou word dat elke spesifieke geskrif oor 'n tydperk kon ontstaan het. Sekere gedeeltes van boeke wat eers later finaal voltooi is kan dus uit 'n vroeër tyd stam. Binne elke tydvak van Israel se geskiedenis moet die spesifieke literatuur van daardie tydvak onder die loep geneem word en daar moet gepoog word om rekenskap te gee van moontlike tendense in die literatuur wat weer moontlik met ander sosio-kulturele politieke en godsdienstige faktore verband hou.

Vir hierdie deel van die studie sal die historikus veral leun op werk wat in die inleidingswetenskap gedoen is (vgl bv Fohrer 1968; Smend 1981; Schmidt 1982b; Rendtorff 1985). Werke wat die literatuur bespreek soos wat dit in die geskiedenis neerslag gevind het (alhoewel nie altyd literatuurgeskiedenisse in die ware sin van die woord nie) is die van Kravitz (1973), Anderson (1984) en Gottwald (1985).

\subsubsection{Samevatting}

Indien die vier aspekte (met die verdere subaspekte) wat hierbo genoem is onder die loep geneem word, word daar nader beweeg aan die ideaal om 'n omvattende beeld van Israel se geskiedenis te verkry. Die voordeel van so ' $n$ benadering is dat so veel as moontlik faktore in aanmerking geneem word wat nie slegs die geskiedenis van Ou-Israel medebepaal het nie, maar wat ook self deel van daardie geskiedenis uitgemaak het.

\subsection{Die chronologiese indeling van Ou-Israel se geskiedenis}

Die skryf van geskiedenis aan die hand van sekere temas of uitstaande gebeurtenisse is ' $n$ moontlikheid waarmee die historikus moet reke- 
ning hou en detail-studies oor sekere aspekte van Ou-Israel se geskiedenis is sekerlik deel van sy taak. Indien dit egter gaan om 'n omvattende geskiedenis van Ou-Israel wat die historikus op die ou end insig moet gee in die geskiedenis van Israel as geheel (en nie slegs deelaspekte daarvan nie), is dit raadsaam om ' $n$ chronologiese indeling te volg. Israel se geskiedenis moet dan in tydvakke of periodes verdeel word wat op mekaar gevolg het. Die probleem is nou dat die geskiedenis hom nie laat voorskryf oor hoe lank sekere periodes moet duur nie. So ' $n$ indeling is derhalwe grootliks gemotiveer deur werksekonomiese motiewe. Sekere periodes sal duidelik van mekaar afgebaken kan word en ander sal weer inmekaar vloei. Die vraag is ook volgens watter kriteria die indeling gemaak moet word. Moet dit volgens argeologiese kriteria wees (steentydperk, bronstydperk, ystertydperk ens), of volgens politieke gebeure en toestande? Ons reken dat laasgenoemde steeds die beste is (omdat die politieke gebeurtenisse sekerlik die ingrypendste in die geskiedenis is), maar dan moet terselfdertyd in gedagte gehou word dat dit hier slegs gaan om 'n raamwerk. Binne hierdie raamwerk moet sosio-kulturele faktore dus steeds hul regmatige plek inneem. 'n Moontlike chronologiese indeling van Ou-Israel se geskiedenis sou so daar kon uitsien:

- Die aartsvadertyd (1800-1300)

- Die eksodus (1300-1200)

- Die intog (1200-1100)

- Die rigtertyd (1100-1000)

- Die verenigde koninkryk (1000-922)

- Die noordryk (922-721)

- Die suidryk (721-587)

- Die ballingskap (587-538)

- Die Persiese tyd (538-322)

- Die Hellenistiese tyd (322-63)

So ' $\mathrm{n}$ indeling is nie noodwendig finaal nie en kan verander word namate meer inligting oor die geskiedenis beskikbaar is en namate die historikus reken dat 'n besondere tydvak meer aandag verdien. So kan sekere tydperke dus saamgevoeg word (bv die Persiese tyd + die Hellenistiese tyd = die na-eksiliese tyd) en ander weer onderverdeel word (die verenigde koninkryk = regering van Saul + Dawid + Salomo). Die historikus kan dan ook leer by indelings wat reeds in verskeie geskiedenisse van Israel gemaak is en hom of haarself afvra waarom die skrywer dit op 'n spesifieke manier gedoen het en wat sy 
indeling van sy eie visie op die geskiedenis van Israel verraai. Sy eie raamwerk verskaf egter aan hom 'n basis waarbinne hy alle bestaande en nuwe informasie kan akkommodeer.

\section{GEVOLGTREKKING}

Ons meen om hierbo aan te getoon het dat die geskiedenis van Ou-Israel ' $n$ meer komplekse saak behels as wat tot ' $n$ groot mate tot dusver rekenskap van gegee is. Uit die aard van die saak is daar wel reeds navorsing op al die genoemde gebiede gedoen. Godsdiensgeskiedenisse, literatuurgeskiedenisse en kultuurgeskiedenisse oor Ou-Israel is volop en is reeds na verwys. Geskiedenisse van Ou-Israel wat al die verskillende aspekte van die lewe van Ou-Israel in die wydste sin van die woord binne een aanbieding integreer is egter skaars. Sodanige geskiedenisse is nodig, aangesien die verskillende aspekte van die lewe in wisselwerking met mekaar staan en wedersydse invloed op mekaar uitoefen. Politiek, godsdiens, kultuur en literatuur bevat elk op sigself dimensies van die ander. Twee gevolgtrekkings kan uit bogenoemde gemaak word:

Eerstens kan die bewering gemaak word dat die hele Ou-Testamentiese wetenskap eintlik die beoefening van geskiedenis behels. Inleidingswetenskap is inderwaarheid niks anders as literatuurgeskiedenis nie. Meer nog: die eksegese van 'n spesifieke gedeelte van die Bybel is niks anders as ' $n$ infokus op ' $n$ klein onderafdeling van die literatuurgeskiedenis nie. Teologie van die Ou Testament is ook niks anders as godsdiensgeskiedenis wat die resepsie van die godsdiens van Ou-Israel tot in die moderne tyd verdiskonteer nie.

Indien 'n komprehensiewe benadering tot die geskiedenis van $\mathrm{Ou}$ Israel gevolg word, het dit tweedens die logiese implikasie dat daar ook 'n komprehensiewe benadering moet wees ten opsigte van die metode wat gevolg word. Dit behels dat die historikus van alle moontlike bronne (Bybels, buite-Bybels, argeologiese artefakte, sekondêre literatuur) en hulpwetenskappe (geografie, sosiologie, psigologie en filosofie) gebruik moet maak. Sommige bronne en hulpwetenskappe verskaf naamlik inligting ten opsigte van spesifieke aspekte van die geskiedenis waar ander weer minder bruikbaar is. Hieroor egter meer in ' $n$ komende ondersoek.

Literatuurverwysings

ANDERSON, BW 1984. The living world of the Old Testament. 3rd ed. Essex: Longman. BULTMANN, R [1926] 1983. Jesus. Tübingen: Mohr. 
DEIST, FE, VOSLOO, W, PRETORIUS, E \& DU PLESSIS, I 1981. Van Eden tot Rome. Pretoria: Van Schaik.

DEIST, FE \& DU PLESSIS, IJ 1982. God and his kingdom. Pretoria: Van Schaik.

DEIST, FE 1986. Tekste met 'n regsperspektief, in Deist, FE et al, Woorde wat van ver kom. Kaapstad: Tafelberg.

DEIST, FE \& LE ROUX, JH 1987. Revolution and reinterpretation. Cape Town: Tafelberg.

DE VAUX, R 1968. Ancient Israel: Its life and institutions. London: Darton.

DEVER, WG 1982. The impact of the 'new archaeology' on Syro-Palestinian archaeology. BASOR 242, 15-29.

FOHRER, G 1968. Introduction to the Old Testament. London: SPCK.

FOHRER, G 1969. Geschichte der israelitischen Religion. Berlin: De Gruyter.

GILBERTSON, MT 1959. The way it was in Bible times. Minneapolis: Augsburg.

GOTTWALD, NK 1985. The Hebrew Bible: A socio-literary introduction. Philadelphia: Fortress Press.

HALLO, WW \& SIMPSON, WK 1971. The Ancient Near East: A history. New York: Harcourt.

HANSON, PD 1979. The dawn of apocalyptic. 2nd ed. Philadelphia: Fortress Press.

HEYNS, M 1986. Die ryk van Israel gedurende die 8e eeu vC: 'n Samelewingsanalise. MA-Verhandeling, Universiteit van Suid-Afrika.

KRAVITZ, N 1973. Three thousand years of Hebrew literature. London: Allen.

NOTH, M 1977. The Old Testament world. London: A \& C Black.

REICKE, B \& ROST, L (reds) 1970. Bijbels-historisch woordenboek. Antwerpen: Het Spectrum.

RENDTORFF, R 1985. The Old Testament: An introduction. London: SCM.

RINGGREN, H 1963. Israelitische Religion. Stuttgart: Kohlhammer.

SCHMIDT, WH 1982a. Alttestamentlicher Glaube in seiner Geschichte. 4. Aufl. Neukirchen: Neukirchener Verlag.

SCHMIDT, WH 1982b. Einführung in das Alte Testament. 2. Aufl. Berlin: De Gruyter. SCHWANTES, SJ 1969.A short history of the Ancient Near East. Grand Rapids: Baker. SMEND, R 1981. Die Entstehung de Alten Testaments. 2. Aufl. Stuttgart: Kohlhammer. VAN ZYL, AH, EYBERS, IH, LE ROUX, JH et al 1979. Israel and her neighbours. Durban: Butterworths.

WISEMAN, DJ (ed) 1973. Peoples of Old Testament Times. Oxford: Claredon. 